\title{
Performance of Chickpea (Cicer arietinum L.) Varieties to Seed Rate and Nipping in Arid Irrigated Western Plain Zone
}

\author{
Ashok Choudhary ${ }^{1 *}$, P. S. Shekhawat ${ }^{1}$, Sheilendra Kumar ${ }^{1}$ and Bheem Pareek $^{2}$ \\ ${ }^{1}$ Swami Keshwanand Rajasthan Agricultural University, Bikaner 334006, India \\ ${ }^{2}$ CSK Himachal Pradesh Agriculture University, Palampur 176062, India \\ *Corresponding author
}

\section{A B S T R A C T}

\begin{tabular}{|c|}
\hline $\begin{array}{l}\text { Ke y w o r d s } \\
\text { Chickpea, Nipping, } \\
\text { Seed rate, Varieties }\end{array}$ \\
\hline Article Info \\
\hline $\begin{array}{l}\text { Accepted: } \\
28 \text { July } 2020 \\
\text { Available Online: } \\
10 \text { August } 2020\end{array}$ \\
\hline
\end{tabular}

A field experiment was conducted during winter season 2016-17 and 2017-18 to study the effect of seed rates and nipping on chick pea varieties. Role of seed rates and nipping was the most important determinant in boosting growth and yield of chickpea varieties. Among varieties, GNG - 1958 recorded significantly higher growth parameters viz., dry matter accumulation, crop growth rate, relative growth rate, leaf area index, chlorophyll content and straw yield of chickpea followed by GNG - 1581 and GNG - 2171. Significantly higher seed yield was recorded by GNG - 1581. Further, growing of chick pea by using an $80 \mathrm{~kg}$ ha-1 seed rate was recorded significantly highest dry matter accumulation, crop growth rate, relative growth rate, index, seed, and straw yield, followed by a seed rate of $64 \mathrm{~kg}$ ha-1 and $48 \mathrm{~kg}$ ha-1. Nipping practices show a significant effect on growth and yield of chickpea. Nipping at 45 DAS observed that higher dry matter accumulation, leaf area index, chlorophyll content, net assimilation rate, seed and straw yield as compared to control (No nipping), nipping at 30 DAS and 60 DAS.

\section{Introduction}

Chickpea (Cicer arietinum L.) is also known as "Gram" or "Bengal gram". It is the most important pulse crop in India. Chickpea belongs to family Leguminosae and originated from north-west India. Chickpea seeds contain about $18-22 \%$ protein, $4-10 \%$ fat and $52-70 \%$ carbohydrate and traditionally consumed after processing into various products. Maharashtra is on the second rank for area 15.41 lakh ha $(17.26 \%)$ and third for production 11.98 lakh tones (14.32\%). Whereas, Rajasthan has the second rank in production $(14.47 \%)$ and third in the area $(15.37 \%)$.

The highest productivity was recorded in the state of Telangana $(1459 \mathrm{~kg} / \mathrm{ha})$ followed by Gujarat (1201 kg/ha) and West Bengal (1163 
$\mathrm{kg} / \mathrm{ha}$ ). The lowest yield was recorded in Karnataka (578 kg/ha). (Annual Report DPD 2016-17). Varieties play an important role in the production and selection of proper variety for a set of agro-climatic conditions it is very important to achieve maximum yield potential. In recent years the development of early varieties of chickpea has enabled its successful cultivation. Inadequate plant population is one of the important factors responsible for poor yields of chickpea (Nagarajaiah et al., 2005). Adequate plant population may be maintained by using good quality optimum seed rate. However, a seed is a costly input and needs to be used judiciously. In chickpea, there is a strong apical dominance; and it is believed that apical meristem/shoot apex produces auxin, which inhibits the axillary buds into actively growing shoots (Campbell et al., 2008). Nipping has been found to increase lateral branches of plants as a result of the removal of the apical dominance of auxin. It promotes the lateral branching, helps to have vigorous plant and produce more flowers and pods. More branches will possibly initiate more flower buds and possibly more yield. (Reddy, 2009). The crop growth and yield of varieties in the changing seed rates and nipping stages help to select the most promising varieties in terms of growth and yield potential. With this view two field experiments were conducted to identify the most suitable variety, appropriate seed rate and nipping stage for the growth and yield performance in chickpea.

\section{Materials and Methods}

The experiment was conducted during winter season 2016-17 and 2017-18 at Instructional Farm, College of Agriculture, Swami Keswanand Rajasthan Agricultural University, Bikaner, Rajasthan, in loamy sand soil of saline reaction having $\mathrm{pH} 8.34$, available nitrogen, phosphorus and potassium $85.31,19.40$ and $315.20 \mathrm{~kg} \mathrm{ha}^{-1}$, respectively in 0-30 $\mathrm{cm}$ soil depth. The experiment was laid out in split-plot design with three replications, assigning 36 treatments consisting three varieties (GNG-1581, GNG1958, and GNG-2171) and three seed rates (48, 64 and $80 \mathrm{~kg} \mathrm{ha}^{-1}$ ) as main plot treatments and four levels of nipping practice (control (no nipping, nipping at 30, 45 and 60 DAS) as subplot treatments. For fertilizer management $20 \mathrm{~kg} \mathrm{~N}$ and $40 \mathrm{~kg} \mathrm{P}_{2} \mathrm{O}_{5} \mathrm{ha}^{-1}$ were applied through DAP and urea, respectively as a basal dose. In the case of weed management, two hand weeding was done at 30 and 45 DAS. Two irrigations were applied at 30 and 60 DAS. The crop was sown at a spacing of $30 \times 10 \mathrm{~cm}$ with a depth of $8 \mathrm{~cm}$ on Nov., 8th 2016 \& Nov., 11th 2017 by the "Kera" method in open furrows.

\section{Results and Discussion}

\section{Growth parameters}

The results revealed that growth parameters viz., dry matter accumulation, crop growth rate, relative growth rate, leaf area index, net assimilation rate and chlorophyll content of chickpea influenced significantly by the different varieties, seed rates and nipping (Table $1 \& 2$ ).

\section{Effect of varieties}

Significantly highest dry matter accumulation plant-1 was observed by variety GNG - 1958 at 30, 60, 90 DAS and at harvest as compared to GNG-1581 and GNG-2171 on pooled basis. This may be due to variation in overall growth and development of individual variety, which indicates more photosynthesis activity. The varietal response in respect of dry matter accumulation was also reported by Kumar et al., (2006). Further results show that variety GNG-1958 produced the highest crop growth rate $\left(\mathrm{g} \mathrm{m}^{-2}\right.$ day $\left.^{-1}\right)$ and relative growth rate over GNG-1581 and GNG-2171 
between 0-30, 30-60, 60-90 DAS and 90 DAS -harvest. The corresponding increase in pooled mean relative growth rate by GNG1958 was to the tune of 38.06 and 49.65 percent between 30-60 DAS, 11.58 and 14.23 percent between 60-90 DAS, 11.74 and 23.43 percent between 90-harvest over GNG-1581 and GNG-2171, respectively. The variation between varieties was also reported by Hasanuzzaman et al., (2007) and Panchariya and Lidder (2000) (Table 1).

Data (Table 2) revealed that variety GNG1581 recorded significantly highest chlorophyll content over the rest of the varieties. The variety GNG-1581 increased in chlorophyll content to the tune of 2.48 and 3.09 percent over GNG-1958 and GNG-2171, respectively. It might be attributed to the development of more leaf area and leaf area index in variety, which ultimately resulted in higher chlorophyll status. Further results show that the highest leaf area index was recorded by variety GNG-1958 as compared to GNG-1581 and GNG-2171 at 30, 60, 90 DAS and at harvest.

A perusal of data (Table 2) revealed that variety GNG-1958 significantly increased the net assimilation rate over the GNG-1581 and GNG-2171 between 30-60 DAS. Whereas at 60-90 DAS GNG-581 significantly increase NAR over GNG- 2171 by 10.61 percent but remained at par with GNG-1958. Further results show that GNG-1581 increased NAR between 90 -harvest over GNG-1958 by 23.65 percent but remained at par with GNG-2171. Similar findings were also reported by Solanki (2008), Panchariya and Lidder (2000).

\section{Effect of seed rate}

Among seed rate of $48 \mathrm{~kg} \mathrm{ha}^{-1}$ was recorded significantly highest growth parameters viz., dry matter accumulation, crop growth rate, relative growth rate, leaf area index, net assimilation rate and chlorophyll content of chickpea over $64 \mathrm{~kg}$ ha- 1 and $80 \mathrm{~kg}$ ha- 1 on pooled basis (Table $1 \& 2$ ).

The highest dry matter accumulation was recorded by the seed rate of $48 \mathrm{~kg} \mathrm{ha}^{-1}$ over seed rate of $64 \mathrm{~kg}$ and $80 \mathrm{~kg} \mathrm{ha}^{-1}$ on pooled mean basis at 60, 90 DAS and harvest. Here the lowest Dry matter accumulation was recorded by the seed rate of $48 \mathrm{~kg} \mathrm{ha}^{-1}$. Dry matter accumulation was increased by seed rate of $48 \mathrm{~kg} \mathrm{ha}^{-1}$ to the tune of 11.40 and 19.91 percent at 60 DAS, 13.15 and 22.15 percent at 90 DAS and 15.17 and 24.38 percent at harvest over the seed rate of $64 \mathrm{~kg}$ and $80 \mathrm{~kg} \mathrm{ha}^{-1}$, respectively.

A seed rate of $48 \mathrm{~kg} \mathrm{ha}^{-1}$ produced highest crop growth rate $\left(\mathrm{g} \mathrm{m}^{-2} \mathrm{day}^{-1}\right)$ and relative growth rate $\left(\mathrm{g} \mathrm{m}^{-2}\right.$ day $\left.^{-1}\right)$ over the seed rate of $64 \mathrm{~kg}$ and $80 \mathrm{~kg} \mathrm{ha}^{-1}$ between 30-60, 60-90 DAS and 90 DAS -harvest. Dry matter per plant exhibited an increasing trend up to maturity in all the treatments; it might be due to the gradual accumulation of food material in different vegetative and reproductive parts of plants. Dry matter accumulation, CGR and RGR per plant increased with a decrease in seed rate and highest dry weight per plant was observed with a seed rate of $48 \mathrm{~kg}$ per hectare (21.27 g).

This could be accounted for the better overall development of individual plants due to lower competition under lower plant density, as it is also evident from the plant character like branches and pod per plant. Under higher seed rates i.e $64 \mathrm{~kg}$ and $80 \mathrm{~kg}$ per hectare, there is a higher competition for various resources particularly light, which may produce a taller plant with fewer branches and pods per plant. Hence the overall dry weight of individual plants was lower. Similar results were also reported by Ray et al., (2017). The highest leaf area index was recorded by seed 
rate of $80 \mathrm{~kg} \mathrm{ha}^{-1}$ as compared to seed rate of $48 \mathrm{~kg}$ and $64 \mathrm{~kg} \mathrm{ha}^{-1}$ at 30, 60, 90 DAS and at harvest on pooled mean basis. The percentage increases in pooled mean leaf area index by seed rate of $80 \mathrm{~kg} \mathrm{ha}^{-1}$ was to the tune of (13.64 and 30.08) at 30 DAS, (7.18 and 5.52) at $60 \mathrm{DAS},(7.52$ and 6.09) at $90 \mathrm{DAS}$ and (7.88 and 6.33) at harvest over seed rate of 48 $\mathrm{kg}$ and $64 \mathrm{~kg} \mathrm{ha}^{-1}$, respectively.

Further results shows that the highest net assimilation rate was recorded by seed rate of $48 \mathrm{~kg} \mathrm{ha}^{-1}$ over the seed rate of $64 \mathrm{~kg}$ and 80 $\mathrm{kg} \mathrm{ha}^{-1}$ between 30-60, 60-90 DAS and 90 DAS -harvest. A seed rate of $48 \mathrm{~kg} \mathrm{ha}^{-1}$ was increases the percentage of net assimilation rate (20.90 \& 44.06) between 30-60 DAS, (17.64 \& 34.96) between 60-90 DAS and (25.24 \& 44.94) between 90-harvest over the seed rate of $64 \mathrm{~kg}$ and $80 \mathrm{~kg} \mathrm{ha}{ }^{-1}$, respectively.

\section{Effect of nipping}

The results (Table 1) revealed that dry matter accumulation at 60 DAS was increased due to nipping at 30 DAS on pooled mean basis over the at control (no nipping), nipping practice 45 and 60 DAS. Whereas, nipping at 45 DAS increased the dry matter accumulation at 90 DAS and at harvest over the control (no nipping), nipping at 45 and 60 DAS. The increase in dry matter accumulation due to nipping at 45 DAS was with the tune of 5.95, 8.39 and 12.14 percent at 90 DAS and 4.64, 8.43 and 12.26 percent at harvest pooled on mean basis.

The treatment of nipping at 45 DAS produced significantly more dry matter as compared to the treatment of no nipping at all stages of crop growth. It may be due to better utilization of available resources with the treatment of nipping which resulted in more photosynthesis and hence the more dry matter was produced. Similar kinds of results were also reported by Sarkar et al., (2010), Reddy et al., (2009). Nipping at 30 DAS increased the CGR at 30-60 over control (No nipping), nipping at 45 and 60 DAS. Whereas, nipping at 45 DAS increased the CGR between 60-90 DAS and at 90- harvest over control (No nipping), nipping at 30 and 60 DAS on pooled mean basis. The percentage increases in pooled mean CGR due to nipping between 45 DAS was to the tune of $(9.54,22.52$ and 19.69) at 60-90 DAS and (1.11, 8.33 and 12.34) between 90 - harvest over control (No nipping), nipping at 30 and 60 DAS, respectively (Table 1).

The significantly higher relative growth rate was obtained by nipping at 30 DAS between 30-60 DAS and 60-90 DAS and between 90 DAS-harvest by nipping at 45 DAS over the rest of the nipping practices on pooled mean (Table 1). The percentage increases in pooled mean RGR due to nipping at 30 DAS was (17.79, 17.79 and 17.07) in 30-60 DAS, (5.19, 3.51 and 7.64) between 60-90 DAS, respectively over control, nipping at 45 and 60 DAS. The corresponding increase in RGR due to nipping at 45 DAS was with the tune of 6.66, 17.55 and 10.76 percent, respectively over control (No nipping), nipping at 30 and 60 DAS on pooled mean basis.

Results (Table 2) revealed that nipping at 45 DAS significantly increases the chlorophyll content over the control, nipping at 30 DAS and nipping at 60 DAS on pooled mean basis. Nipping at 45 DAS increase in 19.06, 8.99 and 12.45 percent of chlorophyll content over control, nipping at 30 DAS and 60 DAS, respectively. Results (Table 2) revealed that nipping at 60 DAS recorded a higher leaf area index at 60 DAS over the control, nipping at 30 and 60 DAS pooled mean basis, but on par with control. Further data shows that nipping at 45 DAS recorded a higher leaf area index at 90 DAS and harvest over control and nipping at 30 DAS, 60 DAS. 
Table.1 Effect of seed rate and nipping dry matter accumulation, crop growth rate and relative growth rate of chickpea varieties (Pooled basis)

\begin{tabular}{|c|c|c|c|c|c|c|c|c|c|c|c|}
\hline \multirow[t]{2}{*}{ Treatment } & \multicolumn{4}{|c|}{ Dry matter accumulation (g plant ${ }^{-1}$ ) } & \multicolumn{4}{|c|}{ Crop growth rate $\left(\mathrm{g} \mathrm{m}^{-2}\right.$ day $\left.^{-1}\right)$} & \multicolumn{3}{|c|}{ Relative growth rate ( $\mathrm{g} \mathrm{g}^{-1}$ day) } \\
\hline & 30 DAS & 60 DAS & 90 DAS & harvest & 0-30 DAS & $\begin{array}{l}\text { 30-60 } \\
\text { DAS }\end{array}$ & $\begin{array}{l}\text { 60-90 } \\
\text { DAS }\end{array}$ & $\begin{array}{l}\text { 90DAS - } \\
\text { harvest }\end{array}$ & 30-60 DAS & $\begin{array}{l}\text { 60-90 } \\
\text { DAS }\end{array}$ & $\begin{array}{l}\text { 90DAS - } \\
\text { harvest }\end{array}$ \\
\hline \multicolumn{12}{|l|}{ (I) Variety } \\
\hline GNG-1581 & 1.89 & 4.94 & 12.74 & 17.92 & 0.063 & 0.102 & 0.260 & 0.173 & 0.0155 & 0.0302 & 0.0264 \\
\hline GNG-1958 & 2.18 & 6.72 & 16.98 & 22.52 & 0.073 & 0.152 & 0.342 & 0.184 & 0.0214 & 0.0337 & 0.0295 \\
\hline GNG-2171 & 1.85 & 4.62 & 11.41 & 16.23 & 0.062 & 0.092 & 0.226 & 0.161 & 0.0143 & 0.0295 & 0.0239 \\
\hline S.Em \pm & 0.02 & 0.07 & 0.18 & 0.22 & 0.001 & 0.002 & 0.006 & 0.002 & 0.0002 & 0.0004 & 0.0004 \\
\hline CD $(5 \%)$ & 0.06 & 0.19 & 0.51 & 0.64 & 0.002 & 0.006 & 0.017 & 0.006 & 0.0007 & 0.0010 & 0.0013 \\
\hline \multicolumn{12}{|c|}{ (II) Seed rate } \\
\hline $48 \mathrm{~kg} \mathrm{ha}^{-1}$ & 2.01 & 5.96 & 15.22 & 21.27 & 0.067 & 0.132 & 0.308 & 0.202 & 0.0192 & 0.0326 & 0.0280 \\
\hline $64 \mathrm{~kg} \mathrm{ha}^{-1}$ & 1.97 & 5.35 & 13.45 & 18.38 & 0.066 & 0.113 & 0.270 & 0.164 & 0.0170 & 0.0308 & 0.0263 \\
\hline $80 \mathrm{~kg} \mathrm{ha}^{-1}$ & 1.94 & 4.97 & 12.46 & 17.02 & 0.065 & 0.101 & 0.250 & 0.152 & 0.0149 & 0.0300 & 0.0254 \\
\hline S.Em \pm & 0.02 & 0.07 & 0.18 & 0.22 & 0.001 & 0.002 & 0.006 & 0.002 & 0.0002 & 0.0004 & 0.0004 \\
\hline CD $(5 \%)$ & NS & 0.19 & 0.51 & 0.64 & NS & 0.006 & 0.017 & 0.006 & 0.0007 & 0.0010 & 0.0013 \\
\hline \multicolumn{12}{|c|}{ III) Nipping stage } \\
\hline Control & 2.00 & 5.29 & 13.77 & 19.16 & 0.067 & 0.110 & 0.283 & 0.180 & 0.0163 & 0.0308 & 0.0270 \\
\hline $\begin{array}{l}\text { Nipping at } \\
\text { 30 DAS }\end{array}$ & 1.96 & 5.88 & 13.46 & 18.49 & 0.065 & 0.131 & 0.253 & 0.168 & 0.0192 & 0.0324 & 0.0245 \\
\hline $\begin{array}{l}\text { Nipping at } \\
45 \text { DAS }\end{array}$ & 1.97 & 5.31 & 14.59 & 20.05 & 0.066 & 0.111 & 0.310 & 0.182 & 0.0163 & 0.0313 & 0.0288 \\
\hline $\begin{array}{l}\text { Nipping at } \\
60 \text { DAS }\end{array}$ & 1.96 & 5.24 & 13.01 & 17.86 & 0.065 & 0.109 & 0.259 & 0.162 & 0.0164 & 0.0301 & 0.0260 \\
\hline S.Em \pm & 0.02 & 0.06 & 0.14 & 0.19 & 0.001 & 0.002 & 0.005 & 0.002 & 0.0003 & 0.0004 & 0.0003 \\
\hline CD (5\%) & NS & 0.18 & 0.39 & 0.53 & NS & 0.006 & 0.013 & 0.006 & 0.0009 & 0.0010 & 0.0010 \\
\hline
\end{tabular}


Table.2 Effect of seed rate and nipping on chlorophyll content, leaf area index and net assimilation rate of chickpea varieties (Pooled basis)

\begin{tabular}{|c|c|c|c|c|c|c|c|c|}
\hline \multirow[t]{2}{*}{ Treatment } & \multirow{2}{*}{$\begin{array}{l}\text { Chlorophyll } \\
\text { content } \\
\left(\mathrm{mg} \mathrm{g}^{-1}\right)\end{array}$} & \multicolumn{4}{|c|}{ Leaf area index } & \multicolumn{3}{|c|}{ Net assimilation $\left(\mathrm{mg}^{-1} \mathrm{~cm}^{2} \mathrm{day}^{-1}\right)$} \\
\hline & & 30 DAS & 60 DAS & 90 DAS & harvest & $\begin{array}{l}\text { 30-60 } \\
\text { DAS }\end{array}$ & $\begin{array}{l}\text { 60-90 } \\
\text { DAS }\end{array}$ & $\begin{array}{c}90 \text { DAS - } \\
\text { harvest }\end{array}$ \\
\hline \multicolumn{9}{|l|}{ (I) Variety } \\
\hline GNG-1581 & 2.598 & 0.127 & 0.719 & 2.209 & 0.985 & 0.299 & 0.198 & 0.115 \\
\hline GNG-1958 & 2.535 & 0.147 & 0.953 & 2.954 & 1.261 & 0.354 & 0.193 & 0.093 \\
\hline GNG-2171 & 2.520 & 0.113 & 0.692 & 2.141 & 0.934 & 0.296 & 0.179 & 0.113 \\
\hline S.Em \pm & 0.009 & 0.002 & 0.004 & 0.014 & 0.015 & 0.006 & 0.004 & 0.001 \\
\hline CD $(5 \%)$ & 0.025 & 0.006 & 0.011 & 0.041 & 0.043 & 0.016 & 0.012 & 0.004 \\
\hline \multicolumn{9}{|l|}{ (II) Seed rate } \\
\hline $48 \mathrm{~kg} \mathrm{ha}^{-1}$ & 2.541 & 0.118 & 0.766 & 2.365 & 1.027 & 0.376 & 0.220 & 0.129 \\
\hline $64 \mathrm{~kg} \mathrm{ha}^{-1}$ & 2.552 & 0.128 & 0.778 & 2.397 & 1.044 & 0.311 & 0.187 & 0.103 \\
\hline $80 \mathrm{~kg} \mathrm{ha}^{-1}$ & 2.558 & 0.140 & 0.821 & 2.543 & 1.108 & 0.261 & 0.163 & 0.089 \\
\hline S.Em \pm & 0.009 & 0.002 & 0.004 & 0.014 & 0.015 & 0.006 & 0.004 & 0.001 \\
\hline CD $(5 \%)$ & NS & 0.006 & 0.011 & 0.041 & 0.043 & 0.016 & 0.012 & 0.004 \\
\hline \multicolumn{9}{|l|}{ (III) Nipping stage } \\
\hline Control & 2.350 & 0.127 & 0.794 & 2.413 & 1.039 & 0.301 & 0.196 & 0.100 \\
\hline Nipping at 30 DAS & 2.567 & 0.128 & 0.774 & 2.395 & 1.017 & 0.364 & 0.177 & 0.107 \\
\hline Nipping at 45 DAS & 2.798 & 0.130 & 0.786 & 2.483 & 1.124 & 0.304 & 0.211 & 0.113 \\
\hline Nipping at 60 DAS & 2.487 & 0.130 & 0.800 & 2.448 & 1.059 & 0.295 & 0.176 & 0.108 \\
\hline S.Em \pm & 0.006 & 0.001 & 0.004 & 0.009 & 0.014 & 0.006 & 0.003 & 0.002 \\
\hline CD $(5 \%)$ & 0.016 & NS & 0.011 & 0.025 & 0.040 & 0.018 & 0.010 & 0.004 \\
\hline
\end{tabular}


Table.3 Effect of seed rate and nipping on seed, straw and biological yield of chickpea varieties

\begin{tabular}{|c|c|c|c|c|c|c|c|c|c|}
\hline \multirow[t]{2}{*}{ Treatment } & \multicolumn{3}{|c|}{ Seed yield $\left(\mathrm{kg} \mathrm{ha}^{-1}\right)$} & \multicolumn{3}{|c|}{ Straw yield $\left(\mathrm{kg} \mathrm{ha}^{-1}\right)$} & \multicolumn{3}{|c|}{ Biological yield $\left(\mathrm{kg} \mathrm{ha}^{-1}\right)$} \\
\hline & 2016-17 & 2017-18 & Pooled & 2016-17 & 2017-18 & Pooled & 2016-17 & 2017-18 & Pooled \\
\hline \multicolumn{10}{|l|}{ (I) Variety } \\
\hline GNG-1581 & 2033 & 2252 & 2142 & 3247 & 3398 & 3323 & 5280 & 5649 & 5465 \\
\hline GNG-1958 & 1843 & 1983 & 1913 & 3569 & 3870 & 3720 & 5412 & 5853 & 5633 \\
\hline GNG-2171 & 1787 & 1891 & 1839 & 3397 & 3755 & 3576 & 5185 & 5646 & 5416 \\
\hline S.Em \pm & 21.63 & 19.96 & 14.71 & 37.88 & 35.94 & 26.11 & 53.85 & 39.40 & 33.36 \\
\hline CD $(5 \%)$ & 64.83 & 59.84 & 42.39 & 113.55 & 107.74 & 75.20 & 161.43 & 118.12 & 96.10 \\
\hline \multicolumn{10}{|l|}{ (II) Seed rate } \\
\hline $48 \mathrm{~kg} \mathrm{ha}^{-1}$ & 1660 & 1764 & 1712 & 3324 & 3604 & 3464 & 4983 & 5368 & 5176 \\
\hline $64 \mathrm{~kg} \mathrm{ha}^{-1}$ & 1991 & 2152 & 2072 & 3354 & 3641 & 3498 & 5345 & 5793 & 5569 \\
\hline $80 \mathrm{~kg} \mathrm{ha}^{-1}$ & 2012 & 2210 & 2111 & 3536 & 3777 & 3657 & 5548 & 5988 & 5768 \\
\hline S.Em \pm & 21.63 & 19.96 & 14.71 & 37.88 & 35.94 & 26.11 & 53.85 & 39.40 & 33.36 \\
\hline CD $(5 \%)$ & 64.83 & 59.84 & 42.39 & 113.55 & 107.74 & 75.20 & 161.43 & 118.12 & 96.10 \\
\hline \multicolumn{10}{|c|}{ (III) Nipping stage } \\
\hline Control & 1777 & 1925 & 1851 & 3317 & 3523 & 3420 & 5094 & 5448 & 5271 \\
\hline $\begin{array}{l}\text { Nipping at } 30 \\
\text { DAS }\end{array}$ & 1854 & 2100 & 1977 & 3391 & 3654 & 3522 & 5245 & 5753 & 5499 \\
\hline $\begin{array}{l}\text { Nipping at } 45 \\
\text { DAS }\end{array}$ & 2083 & 2159 & 2121 & 3543 & 3847 & 3695 & 5626 & 6006 & 5816 \\
\hline $\begin{array}{l}\text { Nipping at } 60 \\
\text { DAS }\end{array}$ & 1837 & 1985 & 1911 & 3368 & 3673 & 3521 & 5205 & 5658 & 5431 \\
\hline S.Em \pm & 19.33 & 19.79 & 13.83 & 34.89 & 36.53 & 25.26 & 44.48 & 34.46 & 28.13 \\
\hline CD (5\%) & 54.81 & 56.10 & 38.77 & 98.94 & 103.58 & 70.81 & 126.11 & 97.71 & 78.87 \\
\hline
\end{tabular}


The percentage leaf area index increases by nipping at 45 DAS was $(2.92,3.67$ and 1.46) at 90 DAS, $(8.17,10.53$ and 6.15$)$ at harvest over control, nipping at 30 and 60 DAS, respectively. The data (Table 2) showed that the net assimilation rate during 30-60 DAS recorded highest by nipping at 30 DAS over the rest of all treatments on pooled mean basis.

Further, data shows that a higher net assimilation rate was recorded by nipping at 45 DAS as compared to the rest of the nipping treatments. The percentage increases in net assimilation rate by nipping at 45 DAS was (7.65, 19.20 and 19.88) between 60-90 DAS, (13.00, 5.60 and 4.62) between 90 DAS harvest over the control (No nipping), nipping at 45 and 60 DAS, respectively.

\section{Yield}

The results (Table 3) revealed that seed, straw and biological yield of chickpea were influenced significantly by the different varieties, seed rates, and nipping during both the years as well as pooled mean basis. Significantly highest seed yield (2033, 2252 and $2142 \mathrm{~kg} \mathrm{ha}^{-1}$ ) was recorded by variety GNG - 1581 as compared to GNG-1958 and GNG-2171 during both the years as well as on pooled basis. This yield variation in respect of various varieties may be due to variation in pod bearing ability, the number of seeds per pod.

This yield variation in respect of various varieties may be due to variation in pod bearing ability, the number of seeds per pod. Similar results were also reported by Nagarjaiah et al., (2005). Further, results shows that variety GNG-1958 recorded significantly higher straw and biological yield as compared to GNG-1581 and GNG-2171 during both the years as well as on pooled basis. The increase in straw yield indirectly related to increases in vegetative growth and a negligible extent the increase in the reproduction portion of the plants. Tiwari (2016) also reported significantly higher straw yield in variety GNG-1958. The highest seed (2012, $2210 \& 2111 \mathrm{~kg} \mathrm{ha}^{-1}$ ), straw (3536, $3777 \& 3657 \mathrm{~kg} \mathrm{ha}^{-1}$ ) and biological yield $\left(5548,5988 \& 5768 \mathrm{~kg} \mathrm{ha}^{-1}\right)$ were observed by $80 \mathrm{~kg} \mathrm{ha}^{-1}$ over seed rate $48 \mathrm{~kg}$ and $64 \mathrm{~kg}$ $\mathrm{ha}^{-1}$ in both the years as well as pooled basis.

The increase in yield attributing characters and yield per plant under lower plant density (seed rate) was not sufficient enough to compensate for the loss in density for higher seed yield. The increase in yield due to a higher seed rate has been also reported by Nagarajaiah et al., (2005). The straw yield increases significantly due to seed rates. A seed rate of $80 \mathrm{~kg}$ per hectare produced significantly higher straw yield per hectare. The total biomass and better environmental conditions resulted in higher straw yield. Similar finding was also reported by Machado et. al. (2005) and Panchariya and Lidder (2000).

Nipping at 45 DAS observed that highest seed (2083, $2159 \& 2121 \mathrm{~kg} \mathrm{ha}^{-1}$ ), straw (3543, $3847 \& 3695 \mathrm{~kg} \mathrm{ha}^{-1}$ ) and biological yield $\left(5626,6006 \& 5816 \mathrm{~kg} \mathrm{ha}^{-1}\right)$ as compared to control (No nipping), nipping at 30 DAS and 60 DAS in the both years as well as pooled basis. The beneficial effect of nipping on biological yield was also reported by Bharathi et al., (2014).

On the basis of two years study GNG-1581 was found to be better variety of chickpea than GNG-1958 and GNG-1581 for western irrigated plain zone of Rajasthan state. Appropriate seed rate for GNG-1581 was found to be $80 \mathrm{~kg} / \mathrm{ha}$ less seed rate led to significant reduction in yield and net return. Nipping practice at 45 DAS in chickpea was also found profitable for Bikaner region. 


\section{References}

Annual report, Directorate of pulse development, Ministry of agriculture \& Farmers Welfare. DPD/Pub/TR/19/2016-17.

Bharathi, K., Panneerselvam, P. and Bhagya, H.P. (2014) Effect of clipping and plant growth regulator along with different kinds of fertilizers on yield and yield parameters in Sesame (Sesamum indicum L.) during the monsoon period. Indian Journal of Agricultural Research 48 (3): 232-236.

Campbell, N.A. Reece JB, Urry LA, Cain ML, Wasserman SA, Minorsky PV, Jackson RB (2008). Biology (8th ed.) Pearson Benjamin Cumming. San Francisco and London: pp. 827-830.

Hasanuzzaman, M., Karim, M.F., Fattah Q.A. and Nahar, K. (2007) Yield performance of chickpea varieties following application of growth regulator. American-Eurasian Journal of Scientific Research 2 (2):117-120.

Kumar S, Kumar M and V.S., Kadion (2006) Biomass partitioning and growth of chickpea (Cicer arietinum L.) as influenced by sowing dates and genotypes. Legume Research 29 (2) : 110-113

Machado, S., Humphreys, C., Tuck, B., Darnell, T. and Corp, M. (2003) Variety, seeding date, spacing and seeding rate effects on grain yield and grain size of chickpea in Eastern Ortegon.Agric. Exper. Station Oregon State Univ. Special Report. pg. 1047

Nagarajaiah, K.M., Palled, Y.B., Patil, B.N., and Khot, A.B., (2005) Responce of Chickpea varieties to seed rate and time of sowing under late sown conditions in Malaprabha Command Area. Karnataka Journal of Agricultural Sciences 18 (3): 609-612.

Panchariya, S K. and Lidder, R.S. (2000) Effect of plant densities on growth and yield of different soybean (Glycine max (L.) Merrill) genotypes M.sc (Ag) thesis J.N.K.V.V. Jabalpur

Ray, Kripanidhi, Singh, Devendra and Jat, Bhanwar Lal (2017). Effect of sowing time and seed rate on growth and yield of chickpea cultivars. Advance Research Journal of Crop Improvement 8 (1) : 1-16,

Reddy, P., Ninganur, B. T., Chetti, M. B., and Hiremath, S. M. (2009) Effect of growth retardants and nipping on chlorophyll content, nitrate reductase activity, seed protein content and yield in cowpea (Vigna unguiculata L.). Karnataka Journal of Agricultural Sciences 22 (2): 289-292.

Tiwari, A.K., (2016) Pulses in India Retrospect \& Prospects Published by Director, Govt. of India, Ministry of Agri. \& Farmers Welfare (DAC\&FW), Directorate of Pulses Development, Bhopal, M.P.- 462004, Publication No.: DPD/Pub.1/Vol. 2.

Venkatachalapathi, V. and S, S. Saini (2003) Influence of seed rate and spatial arrangement on growth and yield of chickpea under late sown condition. Annals of Agricultural Research 24 (3) 693-694.

\section{How to cite this article:}

Ashok Choudhary, P. S. Shekhawat, Sheilendra Kumar and Bheem Pareek. 2020. Performance of Chickpea (Cicer arietinum L.) Varieties to Seed Rate and Nipping in Arid Irrigated Western Plain Zone. Int.J.Curr.Microbiol.App.Sci. 9(08): 3895-3903. doi: https://doi.org/10.20546/ijcmas.2020.908.448 